\title{
Sm-Nd geochronology and petrologic investigation of a sub-ophiolite metamorphic sole from the Dinarides (Krivaja-Konjuh Ophiolite Complex, Bosnia and Herzegovina)
}

\author{
Branimir Šegvić ${ }^{* 1}$, Damir Slovenec ${ }^{2}$, Ralf Schuster ${ }^{3}$, Elvir Babajić ${ }^{4}$, Luka Badurina1 \\ and ${ }^{\dagger}$ Boško Lugović ${ }^{5}$

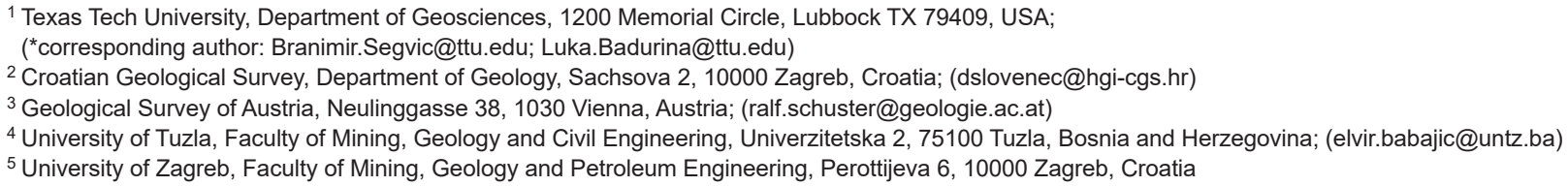

doi: $10.4154 / g c .2020 .09$

Article history:

Manuscript received February 25, 2020

Revised manuscript accepted June 02, 2020 Available online June 30, 2020
Keywords: Dinarides, Sm-Nd ages, high-grade metamorphic sole, Neotethys closure, Jurassic ophiolites

\begin{abstract}
The Dinaridic segment of Neotethys was affected by a widespread shortening and related subduction-accretion-obduction processes that commenced in the middle Jurassic. In the Dinarides, the Krivaja-Konjuh Ophiolite Complex (KKOC) stands as the largest ophiolite complex with a well-exposed metamorphic sole which is the key to understanding the dynamics of intraoceanic subduction initiation in this part of Neotethys. In this contribution we present Sm-Nd geochronology on a granulite facies amphibolite from the KKOC, as well as a detailed petrological description. A five-point isochrone age calculated from clinopyroxene, plagioclase, garnet, amphibole and whole rock is $162 \pm 14 \mathrm{Ma}$ (MSWD =6.2), whereas garnet and whole rock yield $160 \pm 7 \mathrm{Ma}$. Ages calculated from all data points except clinopyroxene are $162 \pm 5 \mathrm{Ma}$ (MSWD $=1.09$ ). Petrographic investigations suggest that these ages date granulite facies metamorphic conditions (i.e. peak metamorphism of Grt-Cpx amphibolite) rather than post-peak exhumation or obduction processes. Phase textural relationships are in line with previous research, which indicated a peak metamorphism equilibration pressure and temperature of $\sim 1 \mathrm{GPa}$ and $\sim 800^{\circ} \mathrm{C}$, respectively. Granulite facies conditions are elucidated for an igneous precursor, which underwent a multi-stage metamorphism that gave rise to recrystallization of igneous clinopyroxene and plagioclase, epitaxial growth of amphibole, and garnet blastosis. Taking into account the age of gabbronorite from the youngest segment of the KKOC oceanic crust (Taorcian to Bathonian) and ages of radiolarian assemblages from the KKOC mélange (Bajocian to Bathonian), it may be inferred that within $\sim 25 \mathrm{Ma}$ the Dinaridic segment of Neotethys evolved rapidly from active ridge spreading through a stage of intraoceanic subduction and arc magmatism toward sub-ophiolite exhumation and further obduction along the Adria passive margin at the end of the Jurassic era.
\end{abstract}

\section{INTRODUCTION}

Stretching discontinuously for about $9500 \mathrm{~km}$, from the European Alps to southern Tibet, the Tethyan ophiolites structurally overlie passive margin successions of collided continents and commonly show fully developed ophiolitic sequences, which also include high-grade sub-ophiolite metamorphic rocks (DILEK \& FURNES, 2019: Fig. 8b, and references therein). The latter are present at the base of many Tethyan ophiolite complexes, which formed at temperatures not exceeding $1200^{\circ} \mathrm{C}$ (e.g. GUILMETTE et al., 2008; SARIFAKIOĞLU et al., 2010; BOROJEVIĆ SOSTARIĆ et al., 2014; KAKAR et al., 2015; MULDER et al., 2016; ŠEGVIĆ et al., 2016). Sub-ophiolite or metamorphic soles are characteristic for subduction realms, more specifically for the zones of high temperatures and variable pressures, which exist below the upper plate's hot sub-oceanic mantle (e.g. PAMIĆ et al., 2002; LÁZARO et al., 2013). Soles emerge in the form of thin dismembered sheets and, therefore, outcrop only sporadically (e.g. POMONIS et al., 2002), yet they are of great geotectonic importance as they adumbrate a shift in the regional dynamics of the oceanic floor (DILEK \& FLOWER, 2003), which provides vital information on the evolution of the ocean as well as on the subsequent ophiolite emplacement history (ÇELIK \& DELALOYE, 2006; PARLAK, 2016).

The Jurassic ophiolites of the Dinarides form a narrow and elongated zone usually divided into two major regional belts - the Central Dinaridic Ophiolite Belt (CDOB) in the west and the Vardar Zone in the east (Fig. 1). There are two schools of thought with respect to the origin of these belts. The first argues for a derivation of both ophiolite belts from the same marginal segment of Neotethys, which ultimately led to the actual position of ophiolites within the Dinarides-Hellenides nappe stack (PAMIĆ et al., 1998; SCHMID et al., 2008; FAUL et al., 2014), while the second one favours the existence of two Neotethyan oceanic branches (e.g. LUGOVIĆ et al., 1991; ROBERTSON, 2004), which were also defined in the Hellenides (FERRIÈRE et al., 2012). Both ophiolitic belts contain high-grade Jurassic metamorphic rocks (e.g. MAJER \& LUGOVIĆ, 1985; GJATA et al., 1992; ROBERTSON \& KARAMATA, 1994; BÉBIEN et al., 2000; SREĆKOVIĆBATOĆANIN et al., 2002; CHIARI et al., 2011). The focus of this study is the metamorphic sole rocks of the Krivaja-Konjuh ophiolite complex (KKOC), which is the biggest ultramafic exposure in the Dinarides (Fig. 1). Amphibolite and granulite dominate the metamorphic suite of the KKOC (PAMIĆ et al., 1977; 

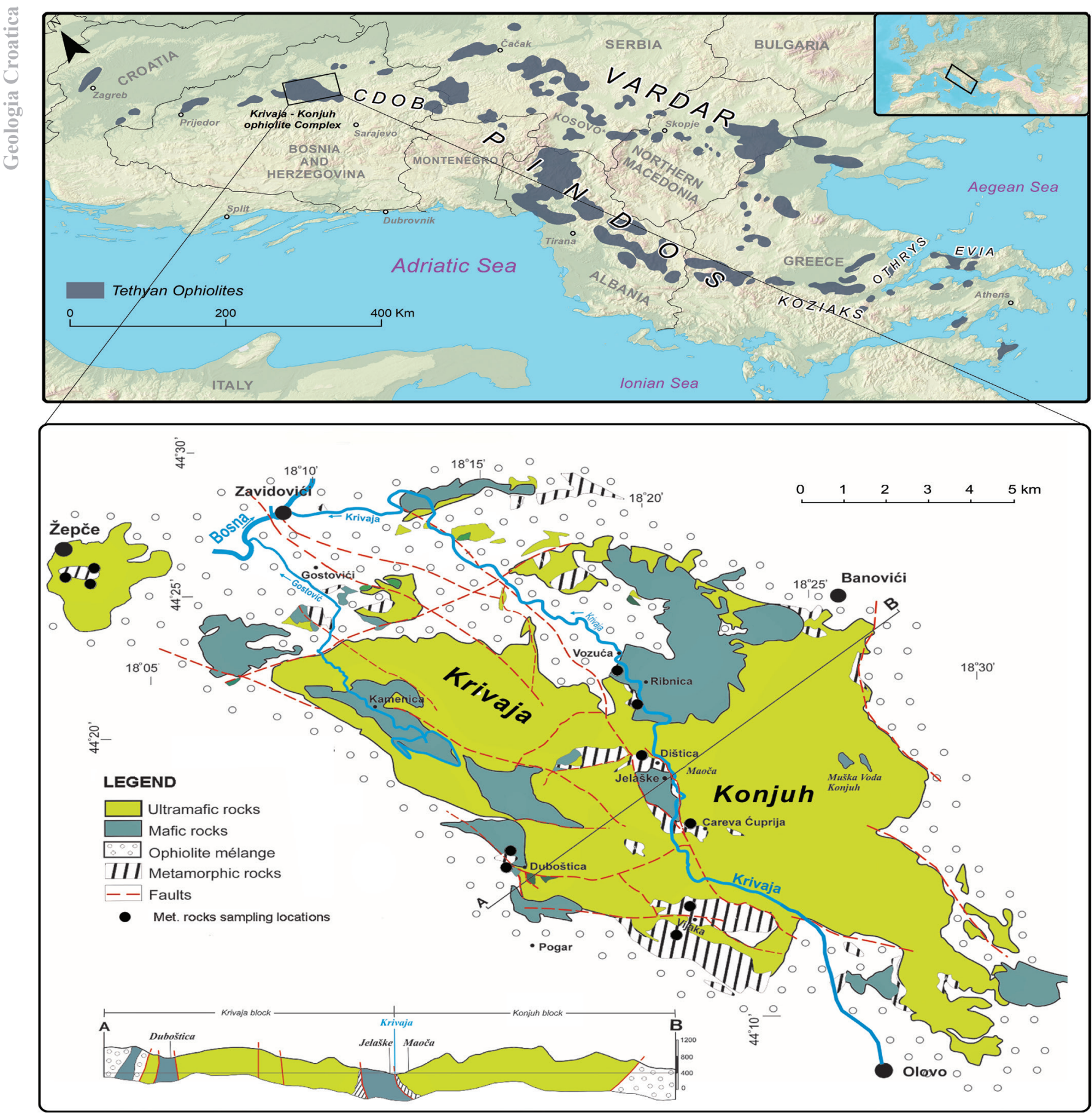

Figure 1. Upper part: A geotectonic schematic map of SE Europe showing the Mesozoic Tethyan ophiolites stretching parallel to the Dinarides. The rectangle indicates the position of the Krivaja-Konjuh ophiolite complex (study area). Map modified after ROBERTSON (2002) and ŠEGVIĆ et al. (2019); Lower part: A simplified geological map of the Krivaja-Konjuh ophiolite complex. Modified after PAMIĆ (1968; 1970), ĐORĐEVIĆ and PAMIĆ (1972), and ŠEGVIĆ et al. (2019). The SW-NE cross-section A-B depicts the tectonic nature of the contact between large blocks of ultramafites and subordinate mafic rocks.

OPERTA et al., 2003). These rocks underwent high temperature metamorphism at variable intermediate pressures (ŠEGVIĆ, 2010). K-Ar dating yielded ages in the range of 170 to $160 \mathrm{Ma}$ (LANPHERE et al., 1975), which correlate relatively well with the dating of radiolarian chert from the KKOC mélange, which was determined to be from Late Bajocian to Early Bathonian in age (ŠEGVIĆ et al., 2014).

The research on orogenic belts has particularly benefited from Sm-Nd geochronology and related P-T-t studies as the former determines the timing of specific tectonic events during the evolution of metamorphic complexes and, therefore, of continen- tal lithosphere (e.g. XU et al., 1994; THÖNI, 2002; PLOTNIKOV et al., 2003; CHENG et al., 2011; DRAGOVIC et al., 2015; CHENG, 2019; WANG et al., 2019). In the high-grade metamorphic assemblage of the metamorphic sole garnet is a critical phase, because it enriches $\mathrm{Sm}$ with respect to $\mathrm{Nd}$, giving the opportunity to measure ages with a precision better than $1 \%$ (e.g. MEZGER et al., 1992; DUTCH \& HAND, 2010; ROMER \& RÖTZLER, 2011; BAXTER et al., 2017). Moreover, the closure temperature of the $\mathrm{Sm}-\mathrm{Nd}$ system in garnet is high enough to define the age of the peak metamorphic assemblage instead of events during the cooling of the system. Careful petrographic and 
Table 1. Sm-Nd isotopic data of sample U-22 from the Krivaja-Konjuh ophiolite complex

\begin{tabular}{lcccc}
\hline Material & $\mathrm{Sm}(\mathrm{ppm})$ & $\mathrm{Nd}(\mathrm{ppm})$ & ${ }^{147} \mathrm{Sm} /{ }^{144} \mathrm{Nd}$ & $\pm 2 \mathrm{~s}_{\mathrm{m}}$ \\
\hline whole rock & 0.518 & 1.087 & 0.2878 & 0.000003 \\
pyroxene & 0.648 & 1.432 & 0.2737 & 0.513115 \\
garnet & 0.311 & 0.367 & 0.5119 & 0.513090 \\
plagioclase & 1.683 & 3.716 & 0.2738 & 0.513349 \\
amphibole & 2.042 & 5.274 & 0.2341 & 0.513101 \\
\hline
\end{tabular}

$\mathrm{Sm}$ and $\mathrm{Nd}$ concentrations were detected by isotope dilution. Nd isotopic ratios are calculated from $650-800$ valid runs at 1.7 to $5.0 \mathrm{~V}$ intensity. Errors are given at the $2 \mathrm{~s}-\mathrm{level}$.

mineralogical considerations are however needed to address the difference.

In this contribution we report a $\mathrm{Sm}-\mathrm{Nd}$ isochron age combined with petrologic observations, which are used to constrain the P-T-t evolution of the metamorphic sole of the KKOC. Several stages of the subduction-extrusion cycle are reconstructed based on metamorphic parageneses and their respective mineral reactions. Details on the Jurassic dynamic evolution in the Dinarides are of broader regional significance as contemporaneous subduction processes took place in the Albanides and Hellednides (BORTOLOTTI et al., 2013; TREMBLAY et al., 2015; KYDONAKIS et al., 2016), while in the Taurides, the subophiolitic sole is largely Cretaceous in age (ÇELIK \& DELALOYE, 2006; ELITOK \& DRÜPPEL, 2008; HÄSSIG et al., 2019).

\section{GEOLOGICAL SETTING}

In the Dinarides a large number of ophiolite rocks occurs either in the form of small blocks ( $\mathrm{m}$ to $\mathrm{km}$ in size) or as large thrust sheets, which may cover as much as $1000 \mathrm{~km}^{2}$ (e.g. TRUBELJA et al., 1995; ك̌SICA et al., 2018). Fragments of the ophiolite sequence are also present in a mélange (Fig. 1; DIMITRIJEVIĆ \& DIMITRIJEVIĆ, 1973; ŠEGVIĆ et al., 2014) consisting of a pelitic to silty sedimentary matrix which incorporated various igneous and sedimentary rocks during tectonic processes (PAMIĆ et al., 2002). Such a mélange is present in the footwall of the ophiolite complexes in the Dinarides (TARI, 2002). The oceanic crust décollement was followed by the Late Jurassic obduction of oceanic crust onto Adria's passive margin (PAMIĆ et al., 1977; CHIARI et al., 2011), which largely explains the recent tectonic position of the Dinaridic ophiolites.

The KKOC is located in central Bosnia and Herzegovina and covers an area of about $650 \mathrm{~km}^{2}$ with a distinct NW-SE elongation (Fig. 1; PAMIĆ et al., 1977; PAMIĆ \& HRVATOVIĆ, 2003). The complex is divided into two large blocks, the western Krivaja block, which represents an amalgamation of ultramafic and mafic rocks, while the eastern Konjuh block largely consists of peridotite (Fig. 1; PAMIĆ, 1968, 1970; ĐORĐEVIĆ \& PAMIĆ, 1972). The ophiolite blocks are tectonically incorporated in a mélange which was thrust onto Lower to Middle Jurassic sedimentary rocks of the Adria continental margin and the whole sequence is overstepped by the Cretaceous basinal Pogari Formation (PAMIĆ, 1970; HRVATOVIĆ, 2006). The reporting of Jurassic foraminifera such as Vidalina martana, Glomospira sp., Cristellaria sp. (PAMIĆ \& HRVATOVIĆ, 2000) from micrite interlayered with shale and greywacke correlates well with the previously mentioned Bajocian to Bathonian age of the radiolarian chert, thus defining the Late Jurassic age of the mélange (ŠEGVIĆ et al., 2014). The KKOC ultramafics are mostly peridotite ( $80 \%$; PAMIĆ, 1968, 1970; ĐORĐEVIĆ \& PAMIĆ, 1972) with some minor dunite and pyroxenite (PAMIĆ et al., 1977; MAKSIMOVIĆ \& MAJER, 1981; LUGOVIĆ et al., 1991; TRUBELJA et al., 1995). The mafic rocks are predominantly represented by gabbro
(PAMIĆ et al., 1977; BABAJIĆ, 2009). In addition to mafic and ultramafic rocks, an elongated zone composed of greenschist to granulite facies metabasaltic and metapelitic rocks occurs discontinuously at the base of the eastern peridotite block (PAMIĆ et al., 1977; OPERTA et al., 2003). The contact of metamorphic rocks with the overlying peridotites is largely syn-metamorphic. Conversely the contact with the mélange has hitherto not been documented (PAMIĆ et al., 2002; ŠEGVIĆ, 2010). At several locations within the complex a clear metamorphic zonation is reported with the granulite exposed adjacent to the peridotite, whereas the rocks of upper and lower amphibolite facies are found further away from the contact (PAMIĆ et al., 1977; ŠEGVIĆ, 2010). Metamorphic conditions of the granulite facies rocks were estimated to be in the range of 850 to $1100{ }^{\circ} \mathrm{C}$ and from 1.1 to $1.3 \mathrm{GPa}$. The protoliths were most likely mafic cumulates formed in a supra-subduction zone setting and to a lesser extent MORB-like mafic extrusives entrained in the subduction/thrusting system as a result of Middle Jurassic contraction of Neotethys (ŠEGVIĆ et al., 2019).

\section{MATERIALS AND METHODS}

Rocks were sampled from 11 locations dispersed throughout the KKOC. In most cases analyzed samples were taken from natural outcrops and only exceptionally, in the event of outcrop inaccessibility, were they gathered from nearby mountain streams. Data on the phase chemistry discussed in this contribution represent a subset of microprobe data given in ŠEGVIĆ et al. (2019) and are provided here as supplementary material (Supplementary material Table 1). The metamorphic P-T space has been defined through the respective reaction curves calibrated in a basaltic system (NCFMASH and CFMASH) (Fig. 5). Reaction curves (1), (2), and (3) are from ERNST and LIU (1988), (4), (5), and (6) from GREEN and RINGWOOD (1967), (7), (8), and (9) from MUKHOPADHYAY and BOSE (1994), (11) and (12) from LIU et al. (1996) and (13) from FREY et al. (1991).

For dating by the Sm-Nd method, sample U22 derived from the prevailing KKOC metamorphic lithotype was carefully chosen to ensure mineral freshness. Mechanical and chemical sample preparation was performed at the Austrian Geological Survey, following the procedure described by SÖLVA et al. (2005). For $\mathrm{Sm}-\mathrm{Nd}$ isotopic analyses a whole rock powder and handpicked mineral separates of garnet, clinopyroxene, plagioclase and amphibole were used. The weights of material used for dissolution were 100 to $200 \mathrm{mg}$. Overall blank contributions were $<200 \mathrm{pg}$ for $\mathrm{Nd}$ and $\mathrm{Sm}$. Isotopic measurements were carried out at the University of Vienna, Austria. Spiked Sm and Nd ratios were measured by a Finnigan ${ }^{\circledR}$ MAT 262, whereas unspiked Nd and Sr ratios were analyzed using a ThermoFinnigan ${ }^{\circledR}$ Triton Thermal Ionisation Mass Spectrometer (TIMS). All elements were run from Re double filaments. On the Triton TI the La Jolla standard yielded ${ }^{143} \mathrm{Nd} /{ }^{144} \mathrm{Nd}=0.511844 \pm 0.000001(2 \sigma)(\mathrm{n}=45)$ during the period of measurements. Errors for the ${ }^{147} \mathrm{Sm} /{ }^{144} \mathrm{Nd}$ 

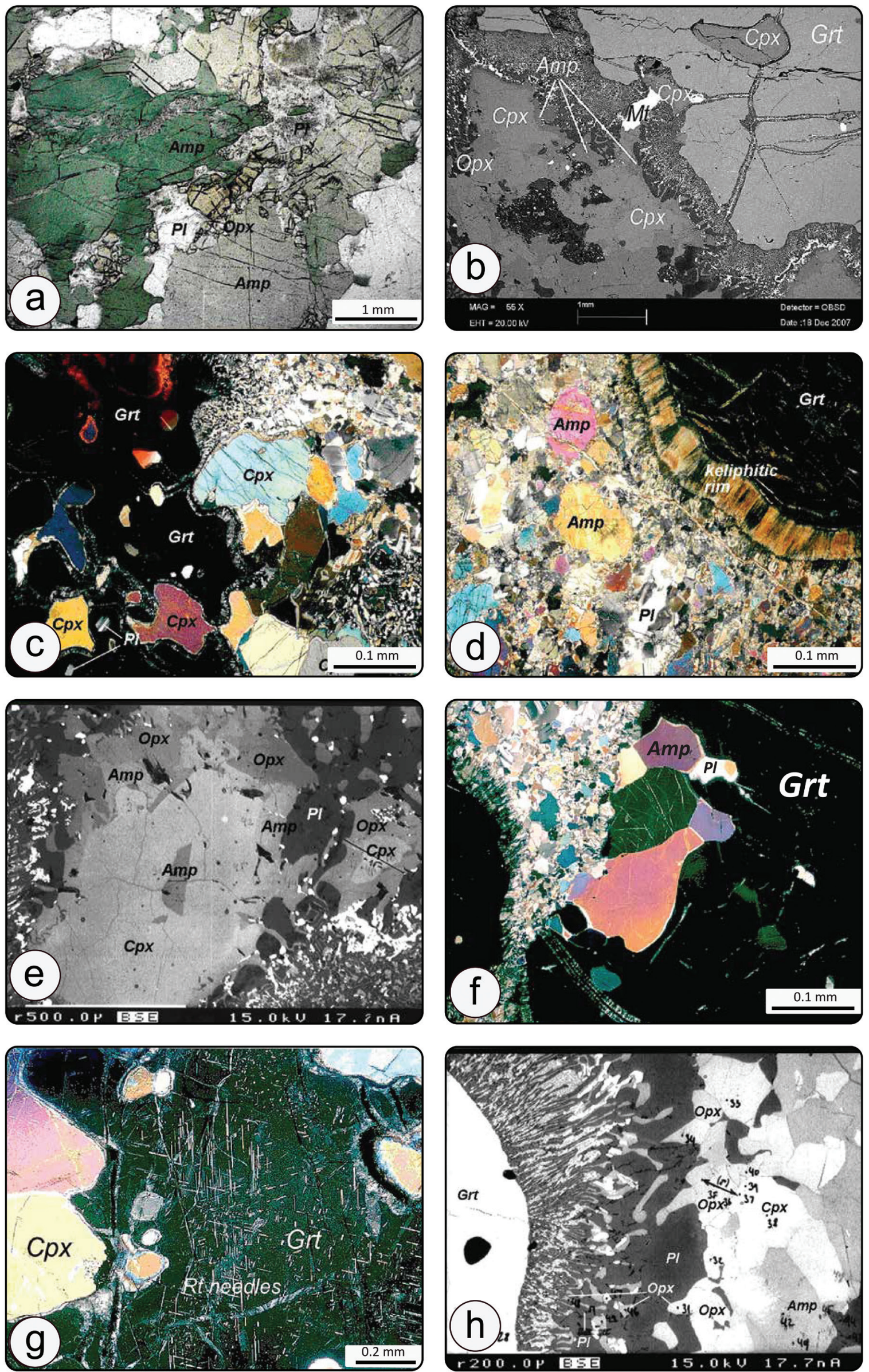

Figure 2. Selected photomicrographs (crossed nicoles, (c), (d), (f), (g); parallel nicoles, (a); and BSE images, (b), (e), (h)) and analyzed rocks. For details see the text; Amp-amphibole; Cpx-clinopyroxene; Opx- orthopyroxene; Mt- magnetite; Grt- garnet; PI- plagioclase; Rt- rutile. Mineral abbreviations after KRETZ (1983). 
ratio are $\pm 1 \%$ or smaller, determined based on iterative sample analysis and spike recalibration. Ages were calculated with the ISOPLOT/Ex software (LUDWIG, 2003).

\section{RESULTS}

\subsection{Petrography}

The texture of high-grade metamorphic rocks of KKOC is granoblastic to porphyroblastic. The former is defined by coarse blasts of amphibole and plagioclase, whereas in the latter one reports on porphyblasts of garnet (up to $1 \mathrm{~cm}$ ) merged in a fine-grained homogenous matrix. Further rock subdivisions have been made based on their geochemistry (i.e. meta-cumulates vs. metabasalts; ŠEGVIĆ et al., 2019). Accordingly, the sapphirine-bearing and corundum-bearing amphibolite, garnet-clinopyroxene ( \pm orthopyroxene) amphibolite and amphibolite per se are classified as metacumulates, whereas clinopyroxene \pm garnet amphibolite and clinopyroxene-plagioclase \pm garnet gneiss represent metabasalts. More details on petrography of KKOC metamorphic rocks may be found in ŠEGVIĆ et al. (2019). Here, further information is provided for garnet-clinopyroxene \pm orthopyroxene (Grt-Cpx $\pm \mathrm{Opx}$ ) amphibolite, which is the most common type of the KKOC metamorphic rocks and was therefore chosen for Sm-Nd dating.

Paragenesis of Grt-Cpx $( \pm \mathrm{Opx})$ amphibolite accounts for garnet, amphibole, clinopyroxene, and plagioclase. Texturally equilibrated orthopyroxene may also emerge as a major paragenetic mineral, appearing in the form of pinkish crystalloblasts (Fig. 2a). Minor phases are Ti-minerals such as rutile, titanite, and ilmenite as well as magnetite. Subrounded porphyroblasts of garnet and lesser amounts of clinopyroxene and amphibole define a porphyroblastic texture (Fig. 2b). Garnet is pyrope to almandine (Supplementary material Table 1) and displays either a characteristic Ushape of its pyrope component or no compositional zonation when equilibrated at peak metamorphic conditions (ŠEGVIĆ et al., 2019). It may contain embedded clinopyroxene, amphibole, plagioclase, rutile and titanite (Fig. 2c). Formation of kelyphitic coronas around some garnet blasts reflects the geochemical disequilibrium of the system after the metamorphic peak (Fig. 2d). Garnet retrograde decomposition gave rise to the formation of secondary Ca-rich plagioclase, orthopyroxene and magnetite, while xonotlite, albite, epidote, pumpellyite and prehnite are reported only sporadically (Fig. 2c). Yet there are numerous grains of garnet, which document peak equilibrium with amphibole and plagioclase. Amphibole's composition spans from edenite to pargasite (Supplementary material Table 1; Fig 7b in ŠEGVIĆ et al., 2019) and is texturally equilibrated with high-Al diopside (Supplementary material Table 1; Fig. 8 b in ŠEGVIĆ et al., 2019). The latter may be found embedded in amphibole, which testifies to the igneous nature of the clinopyroxene (MOAZZEN \& OBERHÄNSLI, 2008). Fine rims of amphibole and orthopyroxene may also be developed around larger crystalloblasts of clinopyroxene (Fig. 2e). This textural feature along with ubiquitous garnet coronas is taken as a sign of incomplete re-equilibration of granulite facies assemblages during later overprints (e.g. GROPPO et al., 2015; ŠEGVIĆ et al., 2019). The An-rich plagioclase is commonly structured within the matrix while large blasts are rare and unrepresentative of plagioclase appearance (Fig. 2a; Fig 8b in ŠEGVIĆ et al., 2019). When present, the non-kelyphitic orthopyroxene is represented by pinkish pleochroitic crystalloblasts texturally equilibrated with amphibole and plagioclase (Fig. 2a). It is primarily hypersthene with 68.2 to $78.6 \mathrm{wt} \%$ En (Supplementary material Table 1; ŠEGVIĆ et al., 2019). Ti-rich phases, rutile and ilmenite, are also abundant in the analyzed amphibolite.

\subsection{Sm-Nd geochronology}

Sm-Nd analyses were performed on clinopyroxene, plagioclase, garnet, amphibole and whole rock separates of sample U22 (Table 1. and Fig. 3). The whole rock, as well as the analyzed minerals are characterized by their low Nd and Sm contents (0.3-5.3 ppm) typical for basaltic rocks. For the whole rock an $\mathrm{e}^{\mathrm{t}} \mathrm{Nd}(\mathrm{Chur})$ value of 7.4 was calculated for $t=160 \mathrm{Ma}$. The lowest ${ }^{147} \mathrm{Sm} /{ }^{144} \mathrm{Nd}$ ratio was measured in amphibole (0.2341), while the whole rock plots in between plagioclase and garnet that display the highest ratio (0.5119). An isochron age calculated from all five data points yields an age of $162 \pm 14 \mathrm{Ma}(\mathrm{MSWD}=6.2)$. The large error and MSWD value are due to a limited spread in the ${ }^{147} \mathrm{Sm} /{ }^{144} \mathrm{Nd} \mathrm{ra-}$ tios and clinopyroxene plotting below the regression line. Ages calculated from all data points except clinopyroxene and from whole rock and garnet only are $162 \pm 5 \mathrm{Ma}(\mathrm{MSWD}=1.09)$ and $160 \pm 7 \mathrm{Ma}$, respectively.

\section{DISCUSSION}

\subsection{P-T-t metamorphic evolution}

Peak-metamorphic conditions of granulite facies can often be reset by diffusion, which is referred to in the literature as the 'granulite uncertainty principle' (HARLEY, 1989). Metamorphic rocks studied herein are suggested to have been formed by a short-time metamorphic overprint induced by the rapid subduction below a hot upper-plate and subsequent rapid cooling during ophiolite exhumation and obduction, thus preserving the peakmetamorphic assemblages intact. The orthopyroxene-free GrtCpx amphibolite analyzed in this contribution is diagnostic for high-grade metamorphic assemblages potentially transitional to eclogite facies (e.g. MUKHOPADHYAY \& BOSE, 1994; PATTISON et al., 2003). The presence of garnet and rutile in metabasite indicates a minimum pressure of 0.8 to $1.0 \mathrm{GPa}$ regardless of the temperature (ERNST \& LIU, 1998). The appearance of clinopyroxene with no orthopyroxene at such pressures denotes a peak temperature in the range of 750 to $800^{\circ} \mathrm{C}$ (GUILMETTE et al., 2008). The amphibole-plagioclase geothermometers yielded equilibration temperatures for this rock type of between 725 to $950{ }^{\circ} \mathrm{C}$. The garnet-clinopyroxene and garnet-amphibole Fe-Mg exchange thermometers also fit the suggested temperature

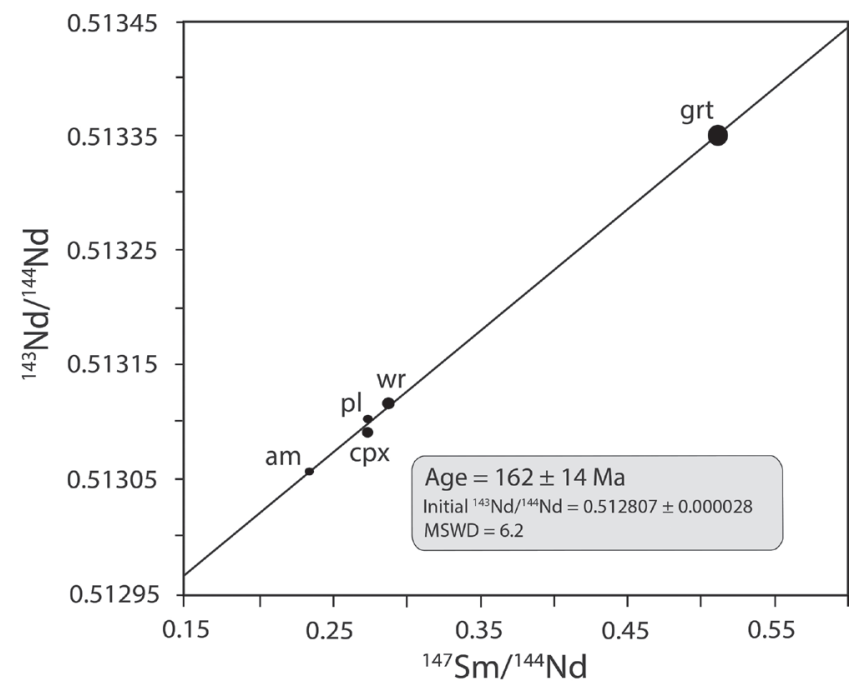

Figure 3. Sm-Nd isochron diagram of Grt-Cpx amphibolite (sample U-22) from the southern parts of the KKOC (Duboštica area). The age and the related initial $\mathrm{Nd}$ ratio is calculated from clinopyroxene, plagioclase, garnet, amphibole and whole rock. 
values (ك̌EGVIĆ et al., 2019). Garnet-clinopyroxene-plagioclase geobarometers consistently show equilibration pressures of 0.94 to $1.30 \mathrm{GPa}$. If orthopyroxene is present, the pressure interval seems to be somewhat narrower ranging from 1.10 to $1.30 \mathrm{GPa}$ (ŠEGVIĆ et al., 2019). We propose a multi-stage metamorphic history for Grt-Cpx amphibolite outlined by the trajectory in Figure 5. The igneous protolith, comprising clinopyroxene and plagioclase, must have undergone a high-grade pressure-dominated amphibolite to granulite facies metamorphism reaching its peak with amphibole consumption (reaction 7 in Fig. 4; MUKHOPADHYAY \& BOSE, 1994; BUCHER \& FREY, 2002). The course of prograde metamorphism is documented by pargasitic substitution in amphibole and is characteristic of the U-shape of the pyrope component in garnet (ŠEGVIĆ et al., 2019). The peak-metamorphic conditions did not last long enough to allow for the complete consumption of amphibole (minimal required temperature of $>850^{\circ} \mathrm{C}$ ), nor any foreign fluid having a low $a \mathrm{H}_{2} \mathrm{O}$ entered the metamorphic system to enhance amphibole dehydration. The course of prograde metamorphism in the Grt-Cpx amphibolite was essentially multifold consisting of three stages: (1) recrystallization of igneous clinopyroxene and plagioclase, (2) epitaxial growth of pargasitic amphibole over clinopyroxene relicts (Fig. 2e), and (3) garnet crystallization at high sub- to super-solidus temperatures $\left(600-800^{\circ} \mathrm{C}\right)$ by the reaction of amphibole and plagioclase that are regularly found as inclusions in garnet (Fig. 2f; reaction 3 in Fig. 4; WOLF \& WYLLIE, 1994). High temperatures of garnet crystallization allowed for the appearance of rutile needles (Fig. 2g), which are normally formed as a response to induced strain in high-grade metabasalts when micro-scale partial melts react with garnet giving rise to the formation of the oriented rutile needles (e.g. HWANG et al., 2007).

High-grade metamorphic conditions inferred for Grt-Cpx amphibolite must have been achieved during the intraoceanic subduction of the Dinaridic part of Neotethys. Thereupon, the peak metamorphic assemblages were altered at continued high temperatures, which led to the formation of well-preserved reaction textures around both garnet and clinopyroxene (Figs. 3d,h; BRANDT et al., 2003; RAO \& CHMIELOWSKI, 2011). For similar metamorphic complexes a mechanism was suggested that involves a reaction of garnet and clinopyroxene with silica, which leads to the formation of orthopyroxene along with plagioclase and magnetite (PRAKASH et al., 2007; Grt + Cpx + silica $\rightarrow$ $\mathrm{Opx}+\mathrm{Pl}+\mathrm{Mt}$ ). Bearing in mind that the analyzed metamorphic rocks are practically quartz-free, silica was likely mobilized by the breakdown of igneous clinopyroxene and its replacement by amphibole ( $\sim 50$ vs. $\sim 40 \mathrm{wt} \% \mathrm{SiO}_{2}$ ). Orthopyroxene from garnet coronas in Grt-Cpx $( \pm \mathrm{Opx})$ amphibolite is rich in $\mathrm{Al}_{2} \mathrm{O}_{3}$ (up to 6.08 wt. \%, ŠEGVIĆ et al., 2019), which testifies to the high-temperature conditions that prevailed during garnet decomposition (HARLEY, 1989). Furthermore, orthopyroxene rims around clinopyroxene (Fig. 2e) are taken as diagnostic for further decompression accompanied by a temperature rise $\left(\sim 50^{\circ} \mathrm{C}\right.$; MUKHOPADHYAY \& BOSE, 1994; TAMASHIRO et al., 2004; SEO et al., 2005). This event must have lasted only for a short time, but long enough to form the discrete orthopyroxene rims. An enhanced retrogression is also indicated by intergrowths of titanite and ilmenite (reaction 11 in Fig. 4), which suggest a rapid cooling and decompression accompanied by hydration (HARLOV et al., 2006). The occurrences of xonotlite, albite, epidote, pumpellyite and prehnite at the expense of decomposing garnet can be linked to this late stage of metamorphism (HACKER \& MOSENFELDER, 1996; DUBACQ et al., 2019). Based on this discussion,

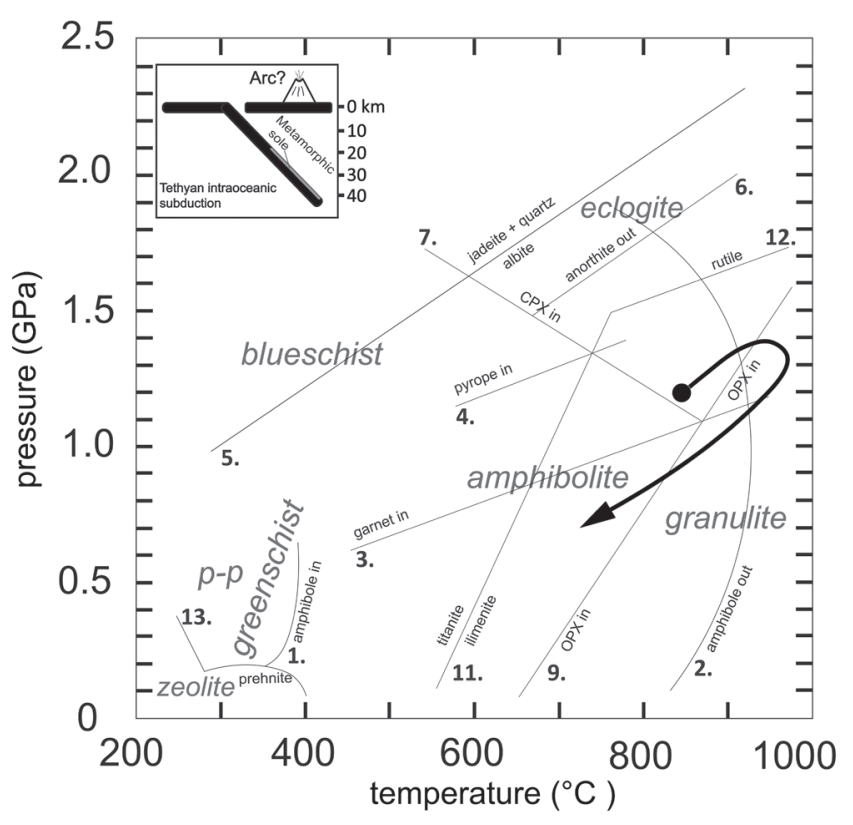

Figure 4. Hypothetical P-T path for Grt-Cpx amphibolite of KKOC. The drawing in the upper left corner depicts a supra-subduction setting in which the metamorphic sole formed.

a prograde pressure dominated high-temperature metamorphism is suggested for the analyzed Grt-Cpx $( \pm \mathrm{Opx})$ amphibolite. This event was followed by decompression induced decomposition of the garnet and orthopyroxene formation during a short temperature rise at moderate pressure conditions. Final cooling and decompression took place under greenschist facies conditions. In the Grt-Cpx $( \pm \mathrm{Opx})$ amphibolite where orthopyroxene emerges as a texturally equilibrated phase (Fig. 2a), the heating event at moderate pressures likely lasted somewhat longer giving rise to the blastosis of orthopyroxene, which may contain inclusions of amphibole. This documents the last temperature rise in this metamorphic system (D’EL-REY SILVA et al., 2007).

\subsection{Sm-Nd geochronology}

The high-grade metamorphic assemblage consisting of fresh garnet, pyroxene and plagioclase was found suitable for dating by the Sm-Nd method and according to the literature this method is characterized by high closure temperatures (e.g. MEZGER et al., 1992; DUTCH \& HAND, 2010). With respect to garnet, varying values of more than 600 or even $800{ }^{\circ} \mathrm{C}$ are suggested for eclogite and granulite facies metabasalt at dry conditions and high cooling rates (JUNG AND METZGER, 2001; THÖNI, 2002). As the investigated rocks experienced temperatures of more than 800 ${ }^{\circ} \mathrm{C}$ and fast cooling, a Sm-Nd isochron defined by the major components will indicate crystallization of the metamorphic peak assemblage instead of later rejuvenations along the cooling path of the rocks.

The age calculated from amphibole, plagioclase, clinopyroxene, garnet and the whole rock yielded $162 \pm 14 \mathrm{Ma}$ (Fig. 3). The large error is also expressed by the mean squared weighted deviation (MSWD) of 6.2, which is a measure for the fit of the data points to the isochron line. As already mentioned in section 4.2., the error is mostly due to clinopyroxene plotting below the regression line, indicating a disequilibrium with respect to the other mineral phases. This disequilibrium might be explained by the petrographic investigations pointing to a partly preserved inherited igneous chemical composition of clinopyroxene (cf. section 

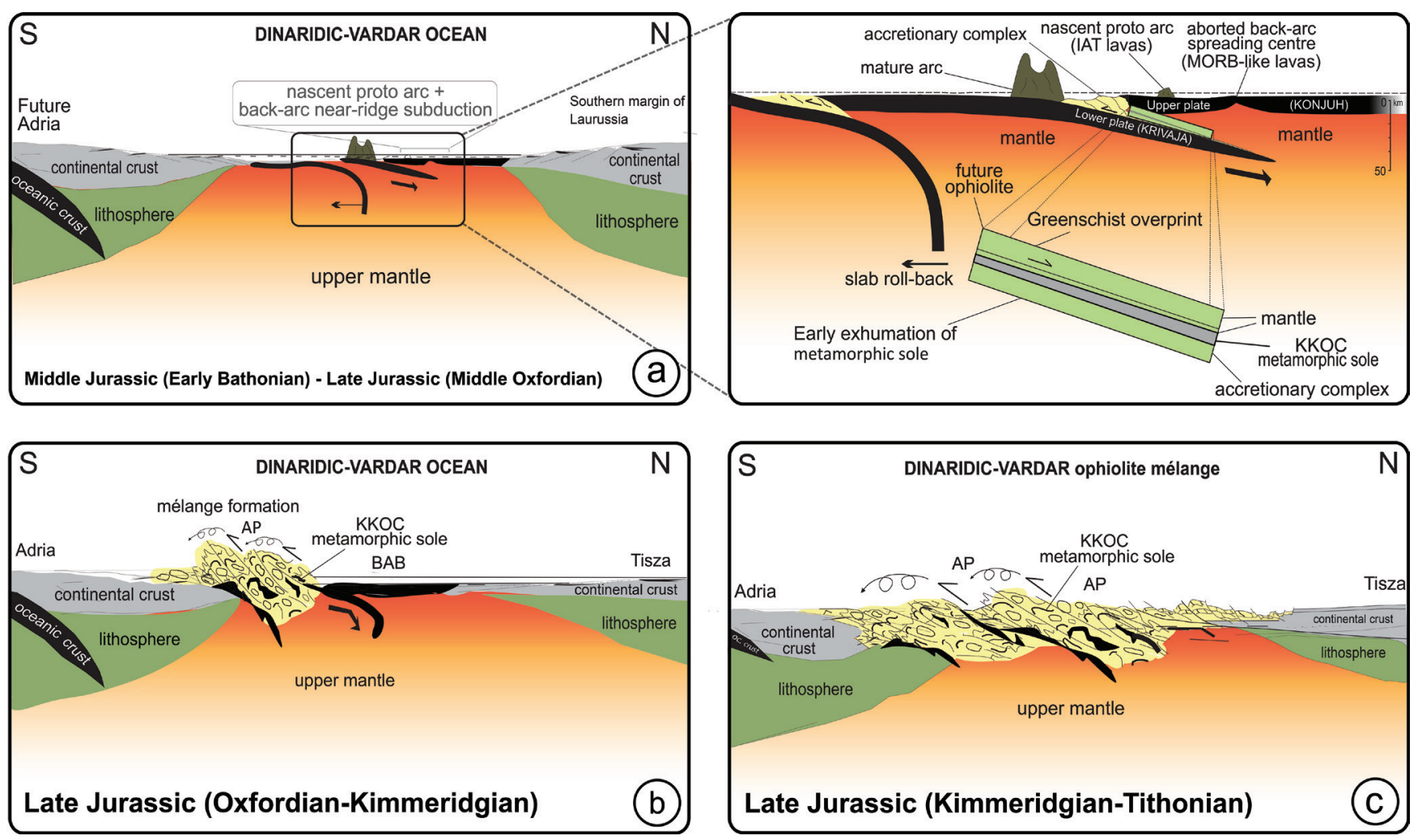

Figure 5. Geodynamic model explaining the formation of the KKOC amphibolites adapted after ŠEGVIĆ et al. (2019). (a) The near-ridge subduction adumbrating the formation of an infant proto arc and aborted spreading centres in the marginal back-arc basin. Sketch detail: intraoceanic subduction stage and formation of metamorphic sole and subsequent early exhumation of metamorphic sole relative to the ophiolite (adapted after WAKABAYASHI and DILEK (2000; 2003). (b) The late subduction stage and progressive accretionary emplacement. (c) The ophiolite and metamorphic sole obduction and final stage of oceanic closure. AP- accretionary prism, BAB- back-arc basin.

4.1.). Therefore, the isochron ages of $162 \pm 5 \mathrm{Ma}(\mathrm{MSWD}=1.09)$ calculated from whole rock, amphibole, plagioclase and garnet or $160 \pm 7 \mathrm{Ma}$ determined from whole rock and garnet are more meaningful. In conclusion, a late Middle to early Late Jurassic age of $160 \pm 7 \mathrm{Ma}$ can be predicted for the crystallization of the peak-assemblage of the Grt-Cpx $( \pm \mathrm{Opx})$ amphibolite. The initial ${ }^{143} \mathrm{Nd} /{ }^{144} \mathrm{Nd}$ ratio is $0.512814 \pm 0.000002$, corresponding to an $\mathrm{e}^{\mathrm{t}}$ $\mathrm{Nd}($ Chur) value of 7.4.

\subsection{Implications for the geology of the Dinarides}

Field evidence and petrogenesis of the KKOC metamorphic rocks adumbrate their genetic link with the adjacent mafic and ultramafic rocks, which are the dominant lithologies of the complex (PAMIĆ et al., 1977; ŠEGVIĆ et al., 2019). This aids the definition of the studied metamorphic rocks as dismembered dynamothermal metamorphic soles formed in a supra-subduction system, where newly born lithosphere remains hot (e.g. ROBERTSON, 2004; SACCANI et al., 2011). In the Dinarides the age of the metamorphic sole has thus far been positioned to the onset of the Oxfordian (e.g. LANPHERE et al., 1975) which is supported by this study (mid-Oxfordian; Fig. 3). This complements well with the latest Bajocian to early Bathonian age of radiolarian assemblages obtained from the chert-rich shaly to silty matrix of the KKOC mélange (ŠEGVIĆ et al., 2014). Taking into account the Sm-Nd age of gabbronorite from the youngest segment of the KKOC oceanic crust, which is set to the Toarcian to Bathonian time (BABAJIĆ, 2009) we argue for a geodynamic evolution that ultimately resulted in intraoceanic subduction and closure of the major part of Neotethys by the end of the Jurassic. High-Ti basalts with N-MORB affinity derived from the tectonic lower plate as well as low-Ti IAT basalts from the upper plate (BABAJIĆ, 2009; ŠEGVIĆ et al., 2019) were both entrained in the mélange of the subduction channel (Fig. 5a). Based on a hypothesized subduction angle $\left(\sim 30^{\circ}\right)$ and an average subduction velocity of $5 \mathrm{~cm}$ per year (e.g. DEWEY, 1981) less than $10 \mathrm{Ma}$ is suggested from initiation of subduction till the down-going plate attained lithospheric depths of the Wadati-Benioff zone (FLOWER et al., 2005). This emphasizes the time needed for a rapid transition of the geological setting in the Dinaridic segment of Neotethys from active ridge magmatism to intraoceanic subduction and related arc volcanism. It took further 5 to $7 \mathrm{Ma}$ for igneous lithologies to attain critical depths in the subduction zone and be metamorphosed at peak conditions of about $800^{\circ} \mathrm{C}$ and $1 \mathrm{GPa}$ during Oxfordian time (Figs. 6a-b). This is in line with the average duration of subduction cycles that last about $5 \mathrm{Ma}$ (MURPHY, 2006). The analyzed sole rocks must have been stripped off from the downgoing plate after the metamorphic peak was reached (Fig. 5b). Exhumed along the ancient subduction channel high-grade metamorphic rocks were thrust onto the Adria margins along with the rest of the ophiolite sequence (PAMIĆ et al., 2002; ROBERTSON et al., 2009a; BORTOLOTTI et al., 2013; ŠEGVIĆ et al., 2016). The exhumation-obduction process was inferred to last between 10 to $15 \mathrm{Ma}$ as otherwise the upper plate would become too thick to obduct onto the continental margin and instead it would bulldoze the margin during the collision (ŠEGVIĆ et al., 2019). According to the scenario proposed herein the main branch of the Dinaridic Neotethys was closed by the end of the Jurassic (Fig. 5c). Obducted ophiolites were partly incorporated in an Early Cretaceous over-stepping cycle by fluvial to shallow marine sediments of the Pogari Formation. In northern Bosnia the latter 
consists of conglomerate, sandstone, and some marly limestone (JOVANOVIĆ, 1961; HRVATOVIĆ, 2006). The remaining backarc basins of the Dinaridic segment of Neotethys, characterized by local extension and back-arc magmatism, did not cease to exist by the end of the Jurassic thus setting the final closure of Neotethys in the Barremian to Aptian times (ROBERTSON et al., 2009b; SLOVENEC \& LUGOVIĆ, 2009; CVETKOVIĆ et al., 2014). The petrogenesis and the Sm-Nd age of the amphibolites from the Krivaja-Konjuh ophiolite complex correspond well to the models suggested for other metamorphic soles reported in the Dinarides (KARAMATA, 1968; TRUBELJA et al., 1995) and the Albanides-Hellenides (GAGGERO et al., 2009; GARTZOS et al., 2009) thus advocating for similar ocean-floor dynamics for large parts of the westernmost Neotethys, now present in the central and eastern Mediterranean.

\section{CONCLUSIONS}

Middle Jurassic time was marked by the regional shortening of oceanic lithosphere of the Dinaridic segment of Neotethys which in turn caused complex subduction-accretion-obduction processes to occur. These developments were parental to the range of Tethyan ophiolite complexes documented throughout the Dinarides and beyond. The Krivaja-Konjuh ophiolite complex of central Bosnia and Herzegovina is the largest complex in the Dinarides and is characterized by numerous exposures of well-preserved metamorphic sole rocks. Welded to the upper peridotite plate during early subduction, the dating of the sole puts effective constraints on the onset of intraoceanic subduction. For the KKOC Grt-Cpx amphibolite, a five point $\mathrm{Sm}-\mathrm{Nd}$ isochrone age was calculated from clinopyroxene, plagioclase, garnet, amphibole and whole rock corresponding to $162 \pm 14 \mathrm{Ma}$ (MSWD = 6.2 ), whereas garnet and whole rock yielded $160 \pm 7 \mathrm{Ma}$. Petrological investigation of the dated amphibolite confirmed that these ages coincide with the peak metamorphism rather than reflecting an event that might have taken place during exhumation or obduction. Peak pressures and temperatures are suggested to revolve around $\sim 1 \mathrm{GPa}$ and $\sim 800^{\circ} \mathrm{C}$ based on the related phase chemistry in textural equilibria. The mafic precursor of the analyzed amphibolite has undergone a multi-stage metamorphism which firstly led to the recrystallization of magmatic clinopyroxene and plagioclase followed by the growth of epitaxial amphibole and garnet blastosis. Comparing the Toarcian to Bathonian age of gabbronorite from the youngest segment of the KKOC oceanic crust and the age of subduction onset in the Dinaridic segment of Neotethys, we propose less than $\sim 25 \mathrm{Ma}$ were needed for the ocean floor rapid transformation from the ridge spreading through intraoceanic subduction to ophiolite obduction along Adria's margins at the end of the Jurassic.

\section{ACKNOWLEDGEMENT}

This work has been supported by the Croatian Ministry of Science, Education and Sport (grant no. 195-1951126-3205 to BL) and in part by the Croatian Science Foundation under the project IP-2019-04-3824. We thank Branka PRŠA for her help with mineral separation. Monika HORSCHINEGG is acknowledged for her assistance performing isotopic measurements. The first author is especially in debt to Vesnica GARAŠIĆ, Vladica CVETKOVIĆ, and Ivan DRAGIČEVIĆ for fruitful scientific discussions at an early stage of the project. Finally, constructive reviews by Kristina ŠARIĆ, Ondrej NEMEC and one anonymous reviewer as well as the editorial handling and suggestions from Dražen BALEN contributed significantly to the quality of the manuscript.

\section{REFERENCES}

BABAJIĆ, E. (2009): Petrološko-geohemijska obilježja mafitnih stijena Krivajskokonjuškog ofiolitnog kompleksa [Petrological and geochemical characteristic of mafic rocks from the Krivanja-Konjuh ophiolitic complex - in Bosnian, with an English Abstract].- PhD Thesis, University of Tuzla, 158 p.

BAXTER, E., CADDICK, M. \& DRAGOVIĆ, B. (2017): Garnet: A rock-forming mineral petrochronometer-- Rev. Mineral. Geochem., 83, no. 1, 469-533.

BÉBIEN, J., DIMO-LAHITTE, A., VERGÉLY, P., INSERGUEIX-FILIPPI, D. \& DUPEYRAT, L. (2000): Albanian ophiolites. I - Magmatic and metamorphic processes associated with the initiation of a subduction.-Ofioliti, 25, 39-45. doi:10.4454/ ofioliti.v25i1.112

BOROJEVIĆ ŠOŠTARIĆ, S., PALINKAŠ, A.L., NEUBAUER, F., CVETKOVIĆ, V., BERNROIDER, M. \& GENSER, J. (2014): The origin and age of the metamorphic sole from the Rogozna Mts., Western Vardar Belt: New evidence for the oneocean model for the Balkan ophiolites.- Lithos, 192-195, 39-55. doi:10.1016/j. lithos.2014.01.011

BORTOLOTTI, V., CHIARI, M., MARRONI, M., PANDOLFI, L., PRINCIPI, G. \& SACCANI, E. (2013): Geodynamic evolution of ophiolites from Albania and Greece (Dinaric-Hellenic belt): one, two, or more oceanic basins?- Int. J. Earth Sci., 102, 783-811. doi:10.1007/s00531-012-0835-7

BRANDT, S., KLEMD, R. \& OKRUSCH, M. (2003): Ultrahigh-Temperature Metamorphism and Multistage Evolution of Garnet-Orthopyroxene Granulites from the Proterozoic Epupa Complex, NW Namibia.- J. Petrol., 44, 1121-1144. doi:10.1093/petrology/44.6.1121

BUCHER, K. \& FREY, M. (2002): Petrogenesis of Metamorphic Rocks.- Springer-Verlag, Berlin, Heidelberg, $341 \mathrm{p}$.

ÇELIK, Ö.F. \& DELALOYE, M.F. (2006): Characteristics of ophiolite-related metamorphic rocks in the Beysehir ophiolitic mélange (Central Taurides, Turkey), deduced from whole rock and mineral chemistry.- J. Asian Earth Sci., 26, 461-476. doi:10.1016/j.jseaes.2004.10.008

CHENG, H., ZHANG, C., VERVOORT, J.D., LI, X., LI, Q., ZHENG, S. \& CAO, D. (2011): Geochronology of the transition of eclogite to amphibolite facies metamorphism in the North Qinling orogen of central China.- Lithos, 125, 969-983. doi:10.1016/j.lithos.2011.05.010

CHENG, H.A.O. (2019): Garnet Lu-Hf and Sm-Nd geochronology: A time capsule of the metamorphic evolution of orogenic belts.- Geol. Soc. Spec. Pub., 474, 47-67. doi:10.1144/SP474.7

CHIARI, M., DJERIĆ, N., GARFAGNOLI, F., HRVATOVIĆ, H., KRSTIĆ, M., LEVI, N., MALASOMA, A., MARRONI, M., MENNA, F., NIRTA, G., PANDOLFI, L., PRINCIPI, G., SACCANI, E., STOJADINOVIĆ, U. \& TRIVIĆ, B. (2011): The geology of the Zlatibor-Maljen area (Western Serbia): A geotraverse across the ophiolites of the Dinaric-Hellenic collisional belt.- Ofioliti, 36, 139-166. doi:10.4454/OFIOLITI.V36.I2.3

CVETKOVIĆ, V., ŠARIĆ, K., GRUBIĆ, A., CVIJIĆ, R. \& MILOŠEVIĆ, A. (2014): The upper Cretaceous ophiolite of North Kozara-remnants of an anomalous midocean ridge segment of the Neotethys.- Geol. Carpath., 65, 117-130. doi:10.2478/ geoca-2014-0008

D'EL-REY SILVA, L.J.H., DANTAS, E.L., TEIXEIRA, J.B.G., LAUX, J.H. \& DA SILVA, M.D.G. (2007): U-Pb and Sm-Nd geochronology of amphibolites from the Curaçá Belt, São Francisco Craton, Brazil: Tectonic implications.- Gondwana Res., 12, 454 467. doi:10.1016/j.gr.2006.11.008

DEWEY, J.F. (1981): Episodicity, sequence and style at convergent plate boundaries.In: The continental crust and its mineral deposits. Geol. Ass. Can., Spec. Paper, 20, 553-572.

DILEK, Y. \& FLOWER, M.F.J. (2003): Arc-trench rollback and forearc accretion: 2. A model template for ophiolites in Albania, Cyprus, and Oman.- Geol. Soc. Spec. Publ., 218, 43-68. doi:10.1144/GSL.SP.2003.218.01.04

DILEK, Y. \& FURNES, H. (2019): Tethyan ophiolites and Tethyan seaways.- J. Geol. Soc., 176, 899-912. doi:10.1144/jgs2019-129

DIMITRIJEVIĆ, M.D. \& DIMITRIJEVIĆ, M.N. (1973): Olistostrome Mélange in the Yugoslavian Dinarides and Late Mesozoic Plate Tectonics.- J. Geol., 81, 328-340.

ĐORĐEVIĆ, D. \& PAMIĆ, J. (1972): Petrološki izvještaj za osnovnu geološku kartu, list Vlasenica [Basic Geological Map of SFRY 1:100000, Vlasenica sheet - in Serbo-Croatian].- Federal Geological Survey, Sarajevo, Belgrade.

DRAGOVIC, B., BAXTER, E.F. \& CADDICK, M.J. (2015): Pulsed dehydration and garnet growth during subduction revealed by zoned garnet geochronology and thermodynamic modeling, Sifnos, Greece.- Earth Planet. Sci. Lett., 413, 111-122. doi:10.1016/j.epsl.2014.12.024

DUBACQ, B., SORET, M., JEWISON, E. \& AGARD, P. (2019): Early subduction dynamics recorded by the metamorphic sole of the Mt. Albert ophiolitic complex (Gaspé, Québec).- Lithos, 334-335, 161-179. doi:10.1016/j.lithos.2019.03.019

DUTCH, R. \& HAND, M. (2010): Retention of Sm-Nd isotopic ages in garnets subjected to high-grade thermal reworking: Implications for diffusion rates of major and rare earth elements and the $\mathrm{Sm}-\mathrm{Nd}$ closure temperature in garnet.- Contrib. Mineral. Petrol., 159, 93-112. doi:10.1007/s00410-009-0418-1 
ELITOK, Ö. \& DRÜPPEL, K. (2008): Geochemistry and tectonic significance of metamorphic sole rocks beneath the Beyșehir-Hoyran ophiolite (SW-Turkey).- Lithos, 100, 322-353. doi:10.1016/j.lithos.2007.06.022

ERNST, W.G. \& LIU, J. (1998): Experimental phase-equilibrium study of Al- and Ticontents of calcic amphibole in MORB; a semiquantitative thermobarometer- Am. Mineral., 83, 952-969. doi:10.2138/am-1998-9-1004

FAUL, U.H., GARAPIĆ, G. \& LUGOVIĆ, B. (2014): Subcontinental rift initiation and ocean-continent transitional setting of the Dinarides and Vardar zone: Evidence from the Krivaja-Konjuh Massif, Bosnia and Herzegovina.- Lithos, 202-203, 283-299. doi:10.1016/j.lithos.2014.05.026

FERRIÈRE, J., CHANIER, F. \& DITBANJONG, P. (2012): The Hellenic ophiolites: eastward or westward obduction of the Maliac Ocean, a discussion.- Int. J. Earth Sci., 101, 1559-1580. doi:10.1007/s00531-012-0797-9

FLOWER, R.M., BOWRING, S.A., TULLOCH, A.J. \& KLEPEIS, K.A. (2005): Tempo of burial and exhumation within the deep roots of a magmatic arc, Fiordland, New Zealand.- Geology, 33, 17-20. doi:10.1130/G21010.1

GAGGERO, L., MARRONI, M., PANDOLFI, L. \& BUZZI, L. (2009): Modeling the oceanic lithosphere obduction: Constraints from the metamorphic sole of Mirdita ophiolites (northern Albania).- Ofioliti, 34, 17-42. doi:10.4454/ofioliti.v34i1.376

GARTZOS, E., DIETRICH, V.J., MIGIROS, G., SERELIS, K. \& LYMPEROPOULOU, T. (2009): The origin of amphibolites from metamorphic soles beneath the ultramafic ophiolites in Evia and Lesvos (Greece) and their geotectonic implication.Lithos, 108, 224-242. doi:10.1016/j.lithos.2008.09.013

GJATA, K., KORNPROBST, J., KODRA, A., BRIOT, D. \& PINEAU, F. (1992): Subduction chaude à l'aplomb d'une dorsale? Exemple des enclaves de pyroxenite à grenat de la breche serpentineuse de Derveni (Albanie). [Hot subduction close to ridge? Examples of the garnet pyroxenite enclaves in the serpentinite breccia at Derveni, Albania - in French, with an English Abstract].- Bull. Soc. Geol. Fr., 163, 469-476.

GREEN, D.H., RINGWOOD, A.E. (1967): The genesis of basaltic magmas.- Contrib. Mineral. Petrol., 15, 103-190.

GROPPO, C., ROLFO, F., LIU, Y.-C., DENG, L.-P. \& WANG, A.-D. (2015): P-T evolution of elusive UHP eclogites from the Luotian dome (North Dabie Zone, China): How far can the thermodynamic modeling lead us?- Lithos, 226, 183-200. doi:10.1016/j.lithos.2014.11.013

GUILMETTE, C., HÉBERT, R., DUPUIS, C., WANG, C. \& LI, Z. (2008): Metamorphic history and geodynamic significance of high-grade metabasites from the ophiolitic mélange beneath the Yarlung Zangbo ophiolites, Xigaze area, Tibet.- J. Asian Earth Sci., 32, 423-437. doi:10.1016/j.jseaes.2007.11.013

HACKER, B.R. \& MOSENFELDER, J.L. (1996): Metamorphism and deformation along the emplacement thrust of the Samail ophiolite, Oman.- Earth Planet. Sci. Lett., 144, 435-451. doi:10.1016/S0012-821X(96)00186-0

HARLEY, S.L. (1989): The origins of granulites: a metamorphic perspective.- Geol. Mag., 126, 215-247. doi:10.1017/S0016756800022330

HARLOV, D., TROPPER, P., SEIFERT, W., NIJLAND, T. \& FÖRSTER, H.-J. (2006): Formation of Al-rich titanite $\left(\mathrm{CaTiSiO}_{4} \mathrm{O}-\mathrm{CaAlSiO}_{4} \mathrm{OH}\right)$ reaction rims on ilmenite in metamorphic rocks as a function of $f \mathrm{H}_{2} \mathrm{O}$ and $f \mathrm{O}_{2}$.- Lithos, 88, 72-84. doi:10.1016/j.lithos.2005.08.005

HÄSSIG, M., ROLLAND, Y., MELIS, R., SOSSON, M., GALOYAN, G. \& BRUGUIER, O. (2019): P-T-T history of the Amasia and Stepanavan sub-ophiolitic metamorphic units (NW Armenia, lesser Caucasus): Implications for metamorphic sole development and for the obduction process.- Ofioliti, 44, 43-70. doi:10.4454/ofioliti.v44i1.464

HRVATOVIĆ, H. (2006): Geološki vodič kroz Bosnu i Hercegovinu. [Geological guide through Bosnia and Herzegovina - in Bosnian, with an English Abstract].- Geol. Survey of Federation of Bosnia and Herzegovina, Ilidža (Sarajevo), 203 p.

HWANG, S. L., YUI, T. F., CHU, H. T., SHEN, P., SCHERTL, H. P., ZHANG, R. Y. \& LIOU, J. G. (2007): On the origin of oriented rutile needles in garnet from UHP eclogites.- J.Metamorph. Geol., 25,349-362. doi:10.1111/j.1525-1314.2007.00699.x

JOVANOVIĆ, R. (1961): Prilog poznavanju prostranstva i facija mezozoika "Unutrašnje zone Dinarida" u NR BiH [On the distribution of Mesozoic facies of the Internal Dinarides in NR BiH - in Serbo-Croatian] - $3^{\text {rd }}$ geological congress of Yugoslavia, The union of geological societies of SFR Yugoslavia, 148-176.

JUNG, S. \& MEZGER, K. (2001): Geochronology in migmatites - a Sm-Nd, U-Pb and $\mathrm{Rb}-\mathrm{Sr}$ study from the Proterozoic Damara belt (Namibia): implications for polyphase development of migmatisation in high-grade terranes.- J. Metamorph. Geol., 19, 77-97. doi: 10.1046/j.0263-4929.2000.00297.x

KAKAR, M.I., MAHMOOD, K., KHAN, M. \& PLAVSA, D. (2015): Petrology and geochemistry of amphibolites and greenschists from the metamorphic sole of the Muslim Bagh ophiolite (Pakistan): implications for protolith and ophiolite emplacement.-Arab. J. Geosci., 8, 6105-6120. doi:10.1007/s12517-014-1613-6

KARAMATA, S. (1968): Zonality in contact metamorphic rocks around the ultramafic mass of Brezovica (Serbia, Yugoslavia).- Proceedings $23^{\text {th }}$ International Geological Congress, 1, 197-207.

KRETZ, R. (1983): Symbols for rock-forming minerals.- Am. Mineral., 68, no. 1-2, 277-279.
KYDONAKIS, K., BRUN, J.-P., POUJOL, M., MONIÉ, P. \& CHATZITHEODORIDIS, E. (2016): Inferences on the Mesozoic evolution of the North Aegean from the isotopic record of the Chalkidiki block.- Tectonophysics, 682, 65-84. doi:10.1016/j. tecto.2016.06.006

LANPHERE, M.A., COLEMAN, R.G., KARAMATA, S. \& PAMIĆ, J. (1975): Age of amphibolites associated with alpine peridotites in the Dinaride ophiolite zone, Yugoslavia.- Earth Planet. Sci. Lett., 26, 271-276. doi:10.1016/0012$821 \mathrm{X}(75) 90001-1$

LÁZARO, C., BLANCO-QUINTERO, I.F., ROJAS-AGRAMONTE, Y., PROENZA, J.A., NÚÑEZ-CAMBRA, K. \& GARCÍA-CASCO, A. (2013): First description of a metamorphic sole related to ophiolite obduction in the northern Caribbean: Geochemistry and petrology of the Güira de Jauco Amphibolite complex (eastern Cuba) and tectonic implications.- Lithos, 179, 193-210. doi:10.1016/j.lithos.2013.08.019

LIU, J., BOHLEN, S.R., ERNST, W.G. (1996): Stability of hydrous phases in subducting oceanic crust.- Earth Planet. Sci. Lett., 143, 161-171.

LUDWIG, K.R. (2003): Isoplot 3.00: A geochronological toolkit for Microsoft Excel.Berkeley Geochronology Center Special Publication, 4, 70 p.

LUGOVIĆ, B., ALTHERR, R., RACZEK, I., HOFMANN, A.W. \& MAJER, V. (1991): Geochemistry of peridotites and mafic igneous rocks from the Central Dinaric Ophiolite Belt, Yugoslavia.-Contrib. Mineral. Petrol., 106, 201-216. doi:10.1007/ BF00306434

MAJER, V. \& LUGOVIĆ, B. (1985): Metamorphic rocks from the Ophiolite zone in Banija, Yugoslavia: amphibolites.-Acta Geologica Zagreb, 15, 1-25.

MAKSIMOVIĆ, Z. \& MAJER, V. (1981): Accessory spinels of two main zones of Alpine ultramafic rocks in Yugoslavia.- Bulletin de l'Académie Serbe des Sciences et des Arts, 21, 13-26.

MEZGER, K., ESSENE, E.J. \& HALLIDAY, A.N. (1992): Closure temperatures of the Sm-Nd system in metamorphic garnets.- Earth Planet. Sci. Lett., 113, 397-409. doi:10.1016/0012-821X(92)90141-H

MOAZZEN, M. \& OBERHÄNSLI, R. (2008): Whole rock and relict igneous clinopyroxene geochemistry of ophiolite-related amphibolites from NW Iran Implications for protolith nature.- Neus Jb. Miner. Abh., 185, 51-62. doi:10.1127/00777757/2008/0106

MUKHOPADHYAY, B. \& BOSE, M.K. (1994): Transitional granulite-eclogite facies metamorphism of basic supracrustal rocks in a shear zone complex in the Precambrian shield of South India.- Mineral. Mag., 58, 97-118.

MULDER, J.A., BERRY, R.F., MEFFRE, S. \& HALPIN, J.A. (2016): The metamorphic sole of the western Tasmanian ophiolite: New insights into the Cambrian tectonic setting of the Gondwana Pacific margin.- Gondwana Res., 38, 351-369. doi:10.1016/j.gr.2015.12.010

MURPHY, J.B. (2006): Igneous Rock Associations 7. Arc Magmatism I: Relationship Between Subduction and Magma Genesis.- Geosci. Can., 33, 145-167.

OPERTA, M., PAMIĆ, J., BALEN, D. \& TROPPER, P. (2003): Corundum-bearing amphibolites from the metamorphic basement of the Krivaja-Konjuh ultramafic massif(Dinaride Ophiolite Zone, Bosnia).--Mineral. Petrol., 77, 287-295. doi:10.1007/ s007100300002

PAMIĆ, J. (1968): Petrološki izvještaj za tumač lista Zavidovići, Osnovne Geološke Karte SFRJ [Basic Geological Map of SFRY 1:100000, Zavidovići sheet-in SerboCroatian].- Federal Geological Survey, Sarajevo, Belgrade.

PAMIĆ, J. (1970): Petrološki izvještaj za tumač lista Vareš, Osnovne Geološke Karte SFRJ [Basic Geological Map of SFRY 1:100000, Vareš sheet - in Serbo-Croatian].Federal Geological Survey, Sarajevo, Belgrade.

PAMIĆ, J., GUŠIĆ, I. \& JELASKA, V. (1998): Geodynamic evolution of the Central Dinarides.- Tectonophysics, 297, 251-268. doi:10.1016/S0040-1951(98)00171-1

PAMIĆ, J. \& HRVATOVIĆ, H. (2000): Dinaride Ophiolite Zone (DOZ). Basic data on the geology and petrology of the Krivaja-Konjuh ophiolite complex. Pancardi 2000 fieldtrip guidebook.- Vijesti Hrvatskoga geološkog društva, 37, 60-68.

PAMIĆ, J. \& HRVATOVIĆ, H. (2003): Main large thrust structures in the Dinarides - a proposal for their classification.- Nafta, 54, 443-464.

PAMIĆ, J., SUNARIĆ-PAMIĆ, O., OLUJIĆ, J. \& ANTIĆ, R. (1977): Petrografija i petrologija krivajsko-konjuškog ofiolitskog kompleksa i njegove osnovne geološke karakteristike: Geology, petrography, and petrology of the Krivaja-Konjuh ophiolite complex in the central part of the Dinarides, Yugoslavia.- Acta Geologica Zagreb, 9, 59-135.

PAMIĆ, J., TOMLJENOVIĆ, B. \& BALEN, D. (2002): Geodynamic and petrogenetic evolution of Alpine ophiolites from the central and NW Dinarides: an overview.Lithos, 65, 113-142. doi:10.1016/S0024-4937(02)00162-7

PARLAK, O. (2016): The Tauride ophiolites of Anatolia (Turkey): A review.- J. Earth Sci., 27, 901-934. doi:10.1007/s12583-016-0679-3

PATTISON, D.R.M., CHACKO, T., FARQUHAR, J. \& MCFARLANE, C.R.M. (2003): Temperatures of Granulite-facies Metamorphism: Constraints from Experimental Phase Equilibria and Thermobarometry Corrected for Retrograde Exchange.- J. Petrol., 44, 867-900. doi:10.1093/petrology/44.5.867

PLOTNIKOV, A.V., KRUK, N.N., VLADIMIROV, A.G., KOVACH, V.P., ZHURAVLEV, D. Z. \& MOROZ, E.N. (2003): Sm-Nd isotope systematics of metamorphic rocks in the Western Altai-Sayan fold belt.- Dokl. Earth Sci., 388, 63-67. 
POMONIS, P., TSIKOURAS, B. \& HATZIPANAGIOTOU, K. (2002): Origin, evolution and radiometric dating of subophiolitic metamorphic rocks from the Koziakas ophiolite (W. Thessaly, Greece).- Neus Jb. Miner. Abh., 177, 255-276. doi:10.1127/0077-7757/2002/0177-0255

PRAKASH, D., ARIMA, M. \& MOHAN, A. (2007): Ultrahigh-temperature mafic granulites from Panrimalai, south India: Constraints from phase equilibria and thermobarometry.- J. Asian Earth Sci., 29, 41-61. doi:10.1016/j.jseaes.2006.01.002

RAO, C.V.D. \& CHMIELOWSKI, R.M. (2011): New constraints on the metamorphic evolution of the Eastern Ghats Belt, India, based on relict composite inclusions in garnet from ultrahigh-temperature sapphirine granulites.- Geol. J., 46, 240-262. doi:10.1002/gj.1251

ROBERTSON, A.H.F. \& KARAMATA, S. (1994): The role of subduction-accretion processes in the tectonic evolution of the Mesozoic Tethys in Serbia.- Tectonophysics, 234, 73-94. doi:10.1016/0040-1951(94)90205-4

ROBERTSON, A. (2002): Overview of the genesis and emplacement of Mesozoic ophiolites in the Eastern Mediterranean Tethyan region. Lithos, 65, 1-67. https://doi. org/10.1016/S0024-4937(02)00160-3

ROBERTSON, A. (2004): Development of concepts concerning the genesis and emplacement of Tethyan ophiolites in the Eastern Mediterranean and Oman regions.Earth-Sci. Rev., 66, 331-387. doi:10.1016/j.earscirev.2004.01.005

ROBERTSON, A., KARAMATA, S. \& ŠARIĆ, K. (2009a): Overview of ophiolites and related units in the Late Palaeozoic-Early Cenozoic magmatic and tectonic development of Tethys in the northern part of the Balkan region.- Lithos, 108, 1-36. doi:10.1016/j.lithos.2008.09.007

ROBERTSON, A.H.F., KARAMATA, S. \& ŠARIĆ, K. (2009b): Ophiolites and related geology of the Balkan region.-Lithos, 108, vii-x. doi:10.1016/j.lithos.2008.10.013

ROMER, R.L. \& RÖTZLER, J. (2011): The role of element distribution for the isotopic dating of metamorphic minerals.- Eur. J. Mineral., 23, 17-33. doi:10.1127/09351221/2011/0023-2081

SACCANI, E., BECCALUVA, L., PHOTIADES, A. \& ZEDA, O. (2011): Petrogenesis and tectono-magmatic significance of basalts and mantle peridotites from the Albanian-Greek ophiolites and sub-ophiolitic mélanges. New constraints for the Triassic-Jurassic evolution of the Neo-Tethys in the Dinaride sector-- Lithos, 124, 227-242. doi:10.1016/j.lithos.2010.10.009

SARIFAKIOĞLU, E., ÖZEN, H., ÇOLAKOĞLU, A. \& SAYAK, H. (2010): Petrology, mineral chemistry, and tectonomagmatic evolution of Late Cretaceous suprasubduction-zone ophiolites in the Izmir-Ankara-Erzincan suture zone, Turkey.- Int. Geol. Rev., 52, 187-222. doi:10.1080/00206810902818479

SCHMID, S.M., BERNOULLI, D., FÜGENSCHUH, B., MATENCO, L., SCHEFER, S., SCHUSTER, R., TISCHLER, M. \& USTASZEWSKI, K. (2008): The AlpineCarpathian-Dinaridic orogenic system: correlation and evolution of tectonic units.Swiss J. Geosci., 101, 139-183. doi:10.1007/s00015-008-1247-3

ŠEGVIĆ, B. (2010): Petrologic and geochemical characteristics of the Krivaja-Konjuh ophiolite complex (NE Bosnia and Herzegovina) - petrogenesis and regional geodynamic implications.- PhD Thesis, University of Heidelberg, Heidelberg, $310 \mathrm{p}$.

ŠEGVIĆ, B., KUKOČ, D., DRAGIČEVIĆ, I., VRANJKOVIĆ, A., BRČIĆ, V., GORIČAN, Š., BABAJIĆ, E. \& HRVATOVIĆ, H. (2014): New record of Middle Jurassic radiolarians and evidence of Neotethyan dynamics documented in a mélange from the Central Dinaridic Ophiolite Belt (CDOB, NE Bosnia and Herzegovina).-- Ofioliti, 39, 33-43. doi:10.4454/ofioliti.v39i1.427

ŠEGVIĆ, B., LUGOVIĆ, B., SLOVENEC, D. \& MEYER, H.-P. (2016): Mineralogy, petrology and geochemistry of amphibolites from the Kalnik Mt. (Sava Unit, North Croatia): Implications for the evolution of north-westernmost part of the DinaricVardar branch of Mesozoic Tethys.- Ofioliti, 41, 35-58. doi:10.4454/ofioliti. v41i1.441
ŠEGVIĆ, B., SLOVENEC, D., ALTHERR, R., BABAJIĆ, E., MÄHLMANN, R.F. \& LUGOVIĆ, B. (2019): Petrogenesis of high-grade metamorphic soles from the Central Dinaric Ophiolite belt and their significance for the Neotethyan evolution in the Dinarides.- Ofioliti, 44, 1-30. doi:10.4454/ofioliti.v44i1.462

SEO, J., CHOI, S. G., OH, C. W., KIM, S. W. \& SONG, S. H. (2005): Genetic Implications of Two Different Ultramafic Rocks from Hongseong Area in the Southwestern Gyeonggi Massif, South Korea.- Gondwana Res., 8, 539-552. doi:10.1016/ S1342-937X(05)71154-0

SLOVENEC, D. \& LUGOVIĆ, B. (2009): Geochemistry and tectono-magmatic affinity of mafic extrusive and dyke rocks from the ophiolite mélange of the SW Zagorje-Mid-Transdanubian Zone (Mt. Medvednica, Croatia).--Ofioliti; 34, 63-80. doi:10.4454/ofioliti.v34i1.378

SÖLVA, H., GRASEMANN, B., THÖNI, M., THIEDE, R. \& HABLER, G. (2005): The Schneeberg Normal Fault Zone: Normal faulting associated with Cretaceous SE-directed extrusion in the Eastern Alps (Italy/Austria).- Tectonophysics, 401, 143-166. doi:10.1016/j.tecto.2005.02.005

SREĆKOVIĆ-BATOĆANIN, D., MILOVANOVIĆ, D. \& BALOGH, K. (2002): Petrology of the Garnet Amphibolites from the Tejići Village - Povlen Mt., Western Serbia.- Geološki anali balkanskog poluostrva, 64, 187-198.

ŠUICA, S., LUGOVIĆ, B. \& KUKOČ, D. (2018): Tectono-magmatic significance of the pillow basalts from the ophiolitic mélange of the Dinarides.- Ofioliti, 43, 85101. doi:10.4454/ofioliti.v43i1.506

TAMASHIRO, I., SANTOSH, M., SAJEEV, K., MORIMOTO, T. \& TSUNOGAE, T. (2004): Multistage orthopyroxene formation in ultrahigh-temperature granulites of Ganguvarpatti, southern India: implications for complex metamorphic evolution during Gondwana assembly.- J. Mineral. Petrol. Sci., 99, 279-297. doi:10.2465/jmps. 99.279

TARI, V. (2002): Evolution of the northern and western Dinarides: a tectonostratigraphic approach.- EGU Stephan Mueller Special Publication Series, 1, 223-236.

THÖNI, M. (2002): Sm-Nd isotope systematics in garnet from different lithologies (Eastern Alps): age results, and an evaluation of potential problems for garnet Sm-Nd chronometry.-Chem. Geol., 185, 255-281. doi: 10.1016/S0009-2541(01)00410-7

TREMBLAY, A., MESHI, A., DESCHAMPS, T., GOULET, F. \& GOULET, N. (2015): The Vardar zone as a suture for the Mirdita ophiolites, Albania: Constraints from the structural analysis of the Korabi-Pelagonia zone.- Tectonics, 34, 352-375. doi:10.1002/2014TC003807

TRUBELJA, F., MARCHIG, V., BURGATH, K.P. \& VUJOVIĆ, Ž. (1995): Origin of the Jurassic Tethyan Ophiolites in Bosnia: A Geochemical Approach to Tectonic Setting.- Geol. Croat, 48, 49-66.

WAKABAYASHI, J. \& DILEK, Y. (2000): Spatial and temporal relationships between ophiolites and their metamorphic soles: A test of models of forearc ophiolite genesis.- Geol. S. Am. S., 349, 53-64.

WAKABAYASHI, J. \& DILEK, Y. (2003): What constitutes 'emplacement' of an ophiolite?: Mechanisms and relationship to subduction initiation and formation of metamorphic soles.- Geol. Soc. Spec. Publ., 218, 427-447. doi:10.1144/GSL. SP.2003.218.01.22

WANG, D., VERVOORT, J.D., FISHER, C.M., CAO, H. \& LI, G. (2019): Integrated garnet and zircon-titanite geochronology constrains the evolution of ultra-highpressure terranes: An example from the Sulu orogen.- J. Metamorph. Geol., 37, 611-631. doi:10.1111/jmg.12477

WOLF, M.B. \& WYLLIE, P.J. (1994): Dehydration-melting of amphibolite at $10 \mathrm{kbar}$ : the effects of temperature and time.- Contrib. Mineral. Petrol., 115, 369-383. doi:10.1007/BF00320972

XU, B., CHEN, B., ZHANG, C., BAI, Z., WANG, H. \& ZHANG, Q. (1994): Sm-Nd isochron and significance of the Wuhuaoubao block in northern margin of SinoKorean Plate.- Sci. Geol. Sin., 29, 168-172. 


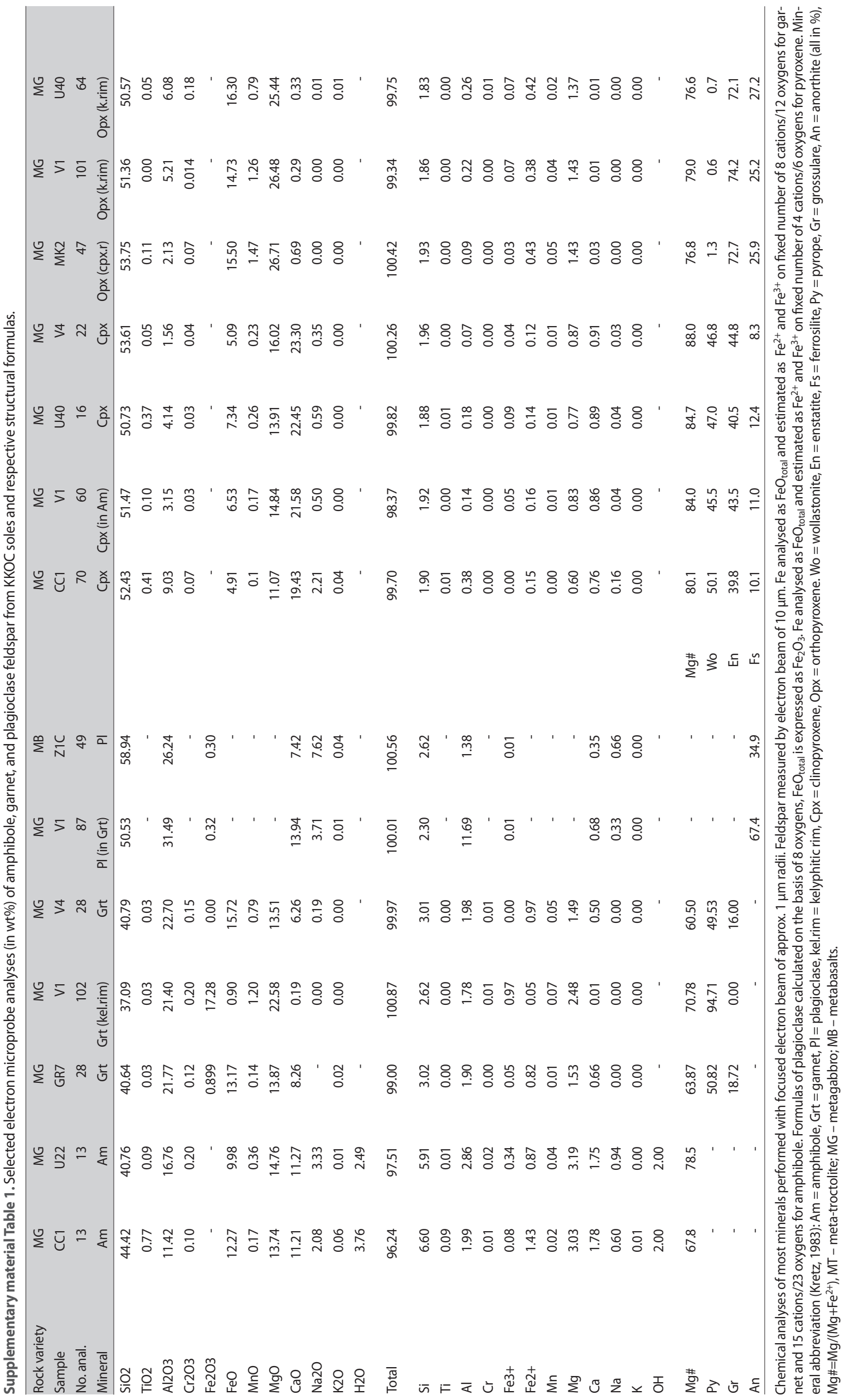


